\title{
Serum Amylase Activity and Its Correlation with Serum Calcium and Albumin
}

\author{
Nabaraj Pokhrel ${ }^{1}$, Usha Shrestha ${ }^{1}$ and Bharat Jha ${ }^{2}$ \\ ${ }^{1}$ National College for Advanced Learning, Lazampat, Kathmandu, Nepal \\ ${ }^{2}$ Institute of Medicine, T. U. Teaching Hospital, Maharajgunj, Kathmandu, Nepal
}

\begin{abstract}
This study was performed in the pathology department of OM Hospital and Research Centre Pvt. Ltd. In this study, amylase, calcium and albumin concentrations in blood serum of 99 subjects visiting this hospital were determined using standard protocol. Out of 99 subjects, 42 were female and 57 were male. Serum amylase activity was found normal in $47 \%$ males and $57 \%$ females, serum level calcium was found normal in $57 \%$ males and $38 \%$ females and serum level of albumin was found normal in $61 \%$ males and $73 \%$ females. The correlation between total corrected calcium and amylase was found slightly positive $(\mathrm{r}=0.01)$. But the correlation between total corrected calcium and albumin and albumin and amylase were found slightly negative $(r=-0.33$ and -0.06 respectively). The study also revealed that low levels of amylase and calcium can be obtained in significant number of subjects.
\end{abstract}

Key Words: blood serum, amylase, albumin, OM hospital

\section{Introduction}

Amylase is derived from the Greek word "amylone," which means starch. It is an enzyme that catalyzes the hydrolysis of starch into smaller carbohydrate molecules. Alpha-amylase, found in saliva, pancreatic juice, malt, certain bacteria, and molds catalyze the hydrolysis of starches to dextrins, maltose, and maltotriose. Betaamylase found in grains, vegetables, malt, and bacteria is involved in the hydrolysis of starch to maltose.

Amylases (E.C. 3.2.1.1; 1,4-alpha-D-Glucan Glucanohydrolase) are a group of hydrolases constituted of ?-D-glucose units linked through carbon atoms 1 and 4 located on adjacent glucose residues (Murray et al. 2003). Amylases are small molecules having molecular weight varying from 55000 to $60000 \mathrm{D}$. The enzyme is thus small enough to pass through the glomeruli of the kidneys but inactivated by tubular epithelium so active enzyme does not appear in urine. Amylase in human is mainly synthesized by the pancreas and salivary glands.

Amylase is measured in patients with suspected pancreatitis, serum and urine levels peak 4-8 $\mathrm{h}$ after onset of acute pancreatitis, and normalize within 48-72 hr. Parotitis due to mumps or radiation therapy also increas serum amylase. The normal range of amylase activity in human serum is $50-150$ Somogyi units $/ 100 \mathrm{ml}$ of blood and 27-96 international unit /1 (Pieper-Bigelow et al. 1990).

The main sources of amylase in humans are the pancreas and salivary glands, but it can be found in other tissues in small quantities. Several isomers of amylase can be identified by electrophoresis, the most abundant are the $\mathrm{P}$ forms derived from the pancreas and the $\mathrm{S}$ form of salivary origin (Pieper-Bigelow et al. 1990).

During acute pancreatitis, enzymes that normally flow from the pancreas into the digestive tract leak out of the pancreas into the bloodstream. A serum amylase test determines levels of amylase in a blood sample. A marked increase (more than three times the upper limit of normal) strongly suggests acute pancreatitis. However, levels of these enzymes may be only slightly elevated in people with chronic pancreatitis (http:/ www.uptodate.com).

Amylases are calcium metalloenzymes, and hence is absolutely required for the functional integrity. This study is mainly concerned with the amylase activity 
in human serum. Beside this, serum level of calcium and albumin were also determined to determine correlation between corrected calcium value and amylase activity.

\section{Materials and Methods}

For this study: test tubes, disposable plastic tubes, amylase kit, calcium kit, albumin kit, automated analyzer, spectrocolorimeter, waterbath, micropipettes, centrifuge, etc were used. Approximately $5 \mathrm{ml}$ venous blood samples of 99 different subjects were collected by means of vein puncture and the collected blood was kept in an incubator at $37^{\circ} \mathrm{C}$ and allowed to clot. It was then centrifuged at $3000 \mathrm{rpm}$ for $10 \mathrm{~min}$. Then the serum was separated and kept in different test tubes under refrigeration. These serums were used to determine serum amylase, calcium and albumin levels at the Department of Pathology, OM Hospital and Research Center.

\section{Estimation of Amylase}

Clean and dry cuvette was taken and the reagent was added in it as follows.

\begin{tabular}{l|l}
\hline Addition sequence & Volume \\
\hline Working solution & $1000 \mu \mathrm{l}$ \\
\hline Serum & $20 \mu \mathrm{l}$ \\
\hline
\end{tabular}

The solution was mixed thoroughly and the cuvette was inserted in the cuvette holder. Then the reading was taken in automated analyzer. The first reading was recorded at 60th second and subsequently three more readings with 30 second interval at $450 \mathrm{~nm}$ and then the average change in absorbance per minute was calculated ( $\mathrm{A} \mathrm{Abs} / 30$ seconds*2)

Activity of amylase in IU/L $=\ddot{A} A b s / \min * 3806$

\section{Estimation of calcium}

Three clean and dry disposable plastic tubes were taken and marked as blank (B), standard (S) and test (T) and reagents were added as follows.

\begin{tabular}{l|c|c|c}
\hline Addition sequence & $\mathrm{B}$ & $\mathrm{S}$ & $\mathrm{T}$ \\
\hline Working reagent* & $1000 \mu \mathrm{l}$ & $1000 \mu \mathrm{l}$ & $1000 \mu \mathrm{l}$ \\
\hline Calcium standard & - & $20 \mu \mathrm{l}$ & - \\
\hline Serum sample & - & - & $20 \mu \mathrm{l}$ \\
\hline
\end{tabular}

*Equal volume of buffer solution and color reagent was mixed as per the requirement.

All the contents of the tubes were mixed well and then allowed to stand at room temperature for five minutes. Then the absorbance of test and standard were measured against blank by using spectrocolorimeter at $576 \mathrm{~nm}$ and calcium concentration was calculated using the following formula.

$$
\text { Serum level of calcium }=\frac{\text { Absorbance of test }}{\text { Absorbance of standard }} \quad \mathrm{X}_{\text {of standard }}^{\text {Concentration }}
$$

\section{Estimation of albumin}

Three clean and dry test tubes were taken and marked as blank (B), standard (S) and test (T) and reagents were added as follows:

\begin{tabular}{l|c|c|c}
\hline Addition sequence & $B$ & $S$ & $T$ \\
Working dye solution & $4000 \mu \mathrm{l}$ & $4000 \mu \mathrm{l}$ & $4000 \mu \mathrm{l}$ \\
Albumin standard & - & $20 \mu \mathrm{l}$ & - \\
Serum & - & - & $20 \mu \mathrm{l}$ \\
\hline
\end{tabular}

All the contents of the tubes were mixed well and then allowed to stand at room temperature for five minutes and then the absorbance of test and standard were measured against blank by using spectrocolorimeter at $620 \mathrm{~nm}$. Albumin concentration was calculated using following formula.

Serum level of albumin $=\frac{\text { Absorbance of test }}{\text { Absorbance of standard }} \quad \mathrm{X} \begin{aligned} & \text { Concentration } \\ & \text { of standard }\end{aligned}$

Finally, the corrected calcium value was determined by using the formula [ Corrected calcium in $\mathrm{mg} / \mathrm{dl}=$ Total calcium in $\mathrm{mg} / \mathrm{dl}+0.8$ (4-albumin in $\mathrm{mg} / \mathrm{dl}$ ] (Burtis et al. 2001)

\section{Results}

Table 1. Status of serum amylase activity

\begin{tabular}{l|l|l}
\hline Serum amylase activity & \multicolumn{2}{|c}{ Gender (\%) } \\
\hline Low $(<27 \mathrm{U} / \mathrm{L})$ & Male & Female \\
Normal $(27-131 \mathrm{U} / \mathrm{L})$ & 52.63 & 38.10 \\
High $(>131 \mathrm{U} / \mathrm{L})$ & 0.37 & 57.14 \\
\hline
\end{tabular}

Out of 99 serum sample analyzed for serum amylase activity, it was found normal in $47.37 \%$ male subjects and $57.14 \%$ female subjects. Elevated level of serum amylase was found only in females but its decreased level was found in both sexes. (Table 1).

Table 2. Status of serum in total corrected calcium concentration serum in total corrected

\begin{tabular}{l|l|l} 
calcium concentration & \multicolumn{2}{|c}{ Gender $(\%)$} \\
\hline Low $(<8.6 \mathrm{mg} / \mathrm{dl})$ & Male & Female \\
Normal $(8.6-10.3 \mathrm{mg} / \mathrm{dl})$ & 40.35 & 54.76 \\
High $(>10.3 \mathrm{mg} / \mathrm{dl})$ & 57.89 & 38.10 \\
\hline
\end{tabular}


Table 2. summarized the status of serum total corrected calcium. The Study found that only $1.75 \%$ males and $7.14 \%$ females had hypercalcimia. On the other hand approximately $50 \%$ patients were suffering from hypocalciamea.

Table 3. Status of serum albumin concentration

\begin{tabular}{l|l|l}
\hline s serum albumin concentration & \multicolumn{2}{|c}{ Gender $(\%)$} \\
\hline & Male & Female \\
Low $(<35 \mathrm{gm} / 1)$ & 38.60 & 26.19 \\
Normal $(35-52 \mathrm{gm} / \mathrm{l})$ & 61.4 & 73.81 \\
High $(>52 \mathrm{gm} / \mathrm{l})$ & 0.00 & 0.00 \\
\hline
\end{tabular}

Table 3 summarizes the status of serum albumin concentration. No case of elevated level of it was found in both sexes. Relatively, more number of females were found with normal albumin concentration in their serum.

\section{Discussion}

á-amylase is produced by the pancreas, hence its appearance in serum is indicative of pancreatic disorders (Murray et al. 2003). In this study, prevalence of hypoamylesemia was found higher than hyperamylesemia in both male and female subjects. High concentration of amylase is found in diseases of pancreas such as pancreatic pseudocyst, and acute pancreatitis (Varley 1988, Mathew 2004). On the other hands the plasma amylase level may be low in liver disease (Murray et al. 2003). Amylase is monitored with chronic pancreatitis. It is often moderately elevated until the cells that produce it are destroyed. Moderate elevation can be observed in pancreatic carcinoma affecting head of pancreas, mumps, salivary gland inflammation, acute exacerbation of chronic pancreatitis and obstruction of pancreatic duct, alcohol poisoning, acute cholecystitis partial gastectomy and intestinal obstruction with strangulation (http:// emedicine.medscape.com/article).

Status of serum total corrected calcium among male and female subjects also reveled that prevalence of hypocalcimia was higher than hypercalcimia in both genders. Lowest value of serum calcium is found in hypoparathyroidism, adult rickets and osteomalacia
(Bhagavan 2002). Values below $6 \mathrm{mg} / \mathrm{dl}$ can be seen in cases of malabsorption syndrome. In Type II nephritis the most characteristic blood changes is the marked fall in plasma albumin, which leads to a reduced serum calcium.

Serum level of albumin was found normal in $61 \%$ male and $74 \%$ female subjects. Unlike amylase and calcium, none of the subjects were found with high level of amylase in their serum. Low concentration of serum albumin is usually due to decreased albumin production, malnutrition, malabsorption, chronic liver disease (e.g., cirrhosis), increased loss of protein (nephrotic syndrome, protein-losing enteropathy), severe burns, during operative procedures.

The correlation between serum amylase activity and serum level total corrected calcium was found positive $(\mathrm{r}=0.01)$. But the correlation between total corrected calcium and albumin and albumin and amylase were found slightly negative $(r=-0.33 \&-0.06$ respectively).

\section{Acknowledgment}

We are thankful to National College for Advance Learning, A Constituent Institution of NIST, Lazimpat, Kathmandu and OM Hospital and Research Centre, Chabahil, Kathmandu, Nepal.

\section{References}

Bhagavan, N.V. 2002. Medical biochemistry. (4th edition). Academic Press (An imprent of Elsevier), Sandigo, USA.

Burtis, C.A, E.R. Ashwood and D.E. Bruns. 2001. Tietz fundamentals of Clinical Chemistry. (5th edition). Harcourt (INDIA) Pvt. Ltd.

Murray, R.K., D.K. Granner, P.A. Mayes and V.W. Rodwell. 2003. Harper's illustrated biochemistry. (26th edition). McGraw-Hill Companies, Inc.

Mathew, K.G (ed). 2004. Preparation manual for undergraduates: medicine. Elsevier India Pvt. Ltd.

Pieper-Bigelow, C, Strocchi, and A. Levitt, M.D. 1990. Where does serum amylase come from and where does it go. Gastroenterol Clin North Am. 19:793.

Varley, H. 1988. Practical clinical biochemistry 4th edition, Indian Edition, CBS Publishers and Distributors, New Delhi 110002. 
Nepal Journal of Science and Technology 10 (2009) 